\title{
Erycius Puteanus' Elogia project, Balduinus Horickius and Chicago, Newberry Library, Wing MS ZW 6465 .H782*
}

\author{
WOUTER BRACKE
}

This article proposes a study of Chicago, Newberry Library, Wing ms ZW 6465 .H782 and analyses its significance for Erycius Puteanus' Elogia project to which the author refers often in his rich correspondence, especially in his letters to Guilliam Blitterswyck. The study also links the ms. to two of Puteanus' minor publications in print, the Podium Philippicum and the Orchestra Burgundica. Lastly, it discusses the lineographic drawings on the background of the calligraphic tradition in the first half of the seventeenth century and more specifically at the court of the governors of the Southern Low Countries.

In 2003 Laurent Guillo studied Chicago, Newberry Library, Wing MS ZW 6465.H782, or Prodigium as he called it after the first word of the inscription on f. 3 , in the framework of his study of a corpus of manuscripts containing seventeenth-century songs and melodies. ${ }^{1} \mathrm{He}$ ascribed the corpus to the Brussels calligrapher Baldericus or Balduinus Horickius (Balderic, or Baudouin, van Horicke $† 1643$ ), whose name is found several times in the Newberry manuscript. A second name that appears in the manuscript is that of Erycius Puteanus (1574-1646), official historiographer at the court of the Archdukes and professor of eloquence at

* Research and writing were made possible thanks to a Short-Term Newberry Library Resident Fellowship (Charles Montgomery Gray Fellowship). I would like to thank Laurent Guillo, as well as the anonymous referees, for their precious comments on a previous version of this article.

1 L. Guillo, "État des recherches sur le Corpus Horicke: quatorze recueils d'airs et de chansons notés sur vélin, illustrés de traits de plume (Bruxelles, ca 1635-1645)", in G. Durosoir (ed.), Poésie, musique et société: l'air de cour en France au XVIII" siècle (Versailles - Liège, 2006), 125-133; Id., "De la gravure au trait de plume: l'illustration des recueils d'airs de cour du Corpus Horicke", in É. Dutray-Lecoin, M. Lefèvre, D. Muzerelle (ed.), Les Plaisirs de l'Arsenal: poésie, musique, danse et érudition au XVII et au XVIII ${ }^{e}$ siècle (Paris, 2018), 349-372. 
the university of Louvain. ${ }^{2} \mathrm{He}$ is considered the author of parts of the manuscript's texts. In the following pages I propose to study more closely this manuscript, its history and its content, in order to better understand Puteanus' role in its production.

Wing MS ZW 6465 .H782 is a peculiar manuscript, for its content and for its form. Measuring $513 \times 368 \mathrm{~mm}$, it has a red morocco binding on marbled boards, with gilt frame of styled leafs and geometrical elements, and gilt edges. On the restored spine board is written in gilt letters Calligraphic drawings Horicquius. It consists of 98 folios and three flyleaves, two in front and one at the end of the volume. Of the 98 folios 63 contain a portrait, (a) figurative or frame drawing(s) on very light laid paper which is pasted on the underlying folios at its four angles and sometimes also in the middle of its superior and/or inferior border. Three watermarks could be found on the drawings: grapes (not in Heawood [henceforth $\mathrm{H}$ ]; variant of Piccard 1110) ${ }^{3}$; circles/arms of Genoa (not in $\left.\mathrm{H}\right) ;{ }^{4}$ double headed eagle/coat of arms (not in H). ${ }^{5}$ The latter type is also found in Horickius' copybooks, Wing MS ZW 6465 .H 781 of the same library, dated 1633, and Munich, Bayerische Staatsbibliothek, Cod. icon. 466 (together with at least one more variant and a similar type without crown), which bears on f. 22 the date 1623 and in any way has to be dated before the end of 1633. Indeed, on f. 1 of the Munich manuscript Horickius calls himself adolescentum honorariorum Serenissimae Infantae formandis characteribus instructor, referring to his teaching at the time of archduchess Isabella of Spain (1566-1633). The watermarks found on the large folios are basically a variant of $\mathrm{H} 1787$. The folios between two subsequent drawings or writings and at the end have the countermark

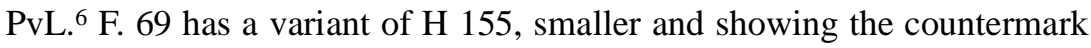
IG (or LG). In the inferior angle of the recto side of some folios bearing eulogies and portraits an alphabetical numeration is found, A, B, C...

2 On Puteanus see T. Simar, Etude sur Erycius Puteanus (1574-1646) considéré spécialement dans l'histoire de la philologie belge et dans son enseignement à l'Université de Louvain (Bruxelles, 1909); "Acta Puteanaea" in Humanistica Lovaniensia 49 (2000), 169-421. Neither of these publications mentions the Newberry manuscript. 67,70 .

${ }^{3}$ Cf. f. $8-11,13-15,18,19,21,23,26-28,30,31,33-35,37,38,39-42$, 44-

4 Cf. f. 12, 16, 17. A variant of this watermark can be found in E. Heawood, "Lafreri maps, 1545-75", The Geographical Journal, 63.5 (1924), 391-410, no. 130.

5 Cf. f. 20, 32, 68, 69.

${ }^{6}$ Churchill 403 (1686) Pieter van der Ley and var433 (1724). 
followed by AA, BB, CC..., which served to keep portrait and accompanying eulogy together, and indicate the order in which the drawings had to be bound in the volume. ${ }^{7}$ For the same reason some of the folios with the initial inscription have traces of a numbering from 1 to 5 .

On the flyleaf at the end of the volume mention is made of "Ricketts 28 ". It refers to the private library of Coella Lindsay Ricketts, a Chicago collector and bookseller, calligrapher and engrosser (1859-1941). ${ }^{8}$ In 1885 he founded in Chicago a firm specializing in calligraphy and illuminations, called The Scriptorium.

Two pieces of paper have slipped into the volume. The first piece of paper mentions notes by a certain Chasse: "See envelope marked Chasse for his and Dr. Rabel's notes on this mss". He could be identified as L.J. Chassee, the author of a manuscript entitled Digest of book written by Balderici Horicquoi consisting of script and pen paintings. The manuscript, Ricketts MS II, 1889-1936, is now kept at the Lilly Library, of the Indiana University at Bloomington, where part of Ricketts's archives went to after his death. The second piece of paper lists the folios where the names of the author, scribe and/or calligrapher are mentioned: "f. 12 Puteanus composuit et Andreas Potheuck scripsit; 16 Erycius Puteanus composuit et Andreas Potheuck scripsit; 24 B.B. Horick invenit 1638; 32 Van den Horicke me scripsit; 22 Baldricus van Horicke invenit; 28 Vanden Horicke fecit; 30 van Horicke 1638; 34 Vanden Horicke". It also bears a reference to a copy of E. De Seyn, Dictionnaire biographique des sciences, des lettres et des arts en Belgique (Bruxelles, 1935-1936) kept in the Newberry Library (folio E 4465.81 ), which does not mention Horickius though. It does mention Puteanus under Cornelis Galle (15701650).

The manuscript's content could be identified as follows:

7 The order of f. 17-18 seems to be mixed up as f. 17 has the accompanying text for Mary of Burgundy, whose picture is on $\mathrm{f}$. 18. Both folios are separated by f. $17 \mathrm{a}$.

8 P.F. Gehl, "Book Arts", in Encyclopaedia of Chicago (Chicago, 2004), available online at http://www.encyclopedia.chicagohistory.org/pages/156.html. 
F. 2 The arms of the Blitterswyck family (Fig. 01). ${ }^{9}$

F. 3-7 contain a large inscription which gives information on the manuscript's authors as well as an approximate date of the intended volume. I will often refer to this inscription in the following pages:

3 Prodigium imo miraculum, / calami vere aurei, / Balderici Horicquii, / scholarcharum sui temporis coryphaei, / epheborum archiducalium / aliorumque / in aula Bruxellensi / puerorum honorariorum, / sub serenissimis principibus / Alberto et Isabella / supremis / fortissimorum Belgarum, / in XVII. olim opulentissimis provinciis, / nimium quam florentium / veterumque Burgundionum, / qui et celeberrimi / sub IV. suis ducibus / populi, / potentissimis aeque ac clementissimis / dynastis

4 nec non / sub serenissimo principe, / Ferdinando Austriaco / Hispaniarum infante, / S.R.E. cardinale, / archiepiscopo Toletano, Philippi IV. / orientis atque occidentis / monarchae / fratris sui / regias vices, / summa cum potestate / nec minori prosperitate / obeunti, / praeceptoris palatini, / qui uti neminem sibi parem /

9 A contemporary drawing of the stemma is conserved in ms. II 2550 of the Royal library of Belgium (f. 18): cf. F. Lyna, Catalogue des manuscrits de la Bibliothèque royale de Belgique, vol. 12 (Renaix, 1936), 273-287, at 275, no. 7537. The project for the lineographic design of the arms is mentioned in a letter by Puteanus to William van Blitterswyck of 1640, where the humanist also offers a subscription he is willing to adapt to Horickius' art: Epistolarum apparatus posthumus in centurias septem distributus opera et industria Xysti Antonii Milseri authoris generi (Lovanii, typis Andreae Bouveti, 1662) [henceforth Epistolarum apparatus posthumus], Centuria VII, ep. 82, 106-107: "Ecce familiae tuae insignia, quemadmodum ea epigrammate complexus sum, quem affectum meum, ut boni consulas, rogo; descriptionem vero aptare potero, ut ab Horickio exprimatur.

BLITTERSWYCKIORUM INSIGNIA GENTILITIA DICTUM $\|$ Ter splendet veteri RADIATUS LU / MINE SANGUIS / INSIGNIA / Inclyta purpureo gens BLITTERS/WYCKIA scuto / argentum triplici dente micante gerit. / Dat galeae radios auro compacta corona: / plumea caesarios sanguine luce fluit. / Surgit apex, alis ramumque virentis olivae / erectus pedibus, sustinet ore lepus. / Quae scutum geminae tollunt galeamque puellae / argento famam, sanguine facta notant. // Facta notant, atavumque genus clarosque / Sicambros, / gloria sic gemina est, ESSE, FUISSE VIROS."

The letter is dated "Lovanii, in Arce v Kal. Novemb. Die Solis, M.DC.XL". The subscription is not found in the manuscript of the Newberry library, but a different version has been conserved in the register of the Rodenbeke family into which William (van) Blitterswijck was accepted on 13 June 1631: cf. J.-T. de Raadt, Sceaux armoriés des Pays-Bas et des pays avoisinants, vol. 1 (Bruxelles, 1898), 146. 
vivens habuerat; / ita filium, quem instruxerat, non imparem / moriens reliquit / et sic, phoenicis instar, / quasi in se ipso revixit/ 5 viri, / in pingendis literis, / si ullus, / rari / in effingendis, / uno eoque nitidissimo, / pennae suae scriptoriae ductu, / politissimis / quarumcumque figurarum speciebus, / unici. / Quod artis suae incomparabilis specimen / hoc in libro, prorsus augusto / et quem inaestimabili praeferas thesauro, / ad stuporem omnium, / septuagenario, quod amplius mireris, / quam sexagenario proximior, / manu, aetate sua firmiori, / efformavit, exaravit / parergisque elegantissimis exornavit, / imo adumbravit.

6 Quod pulcherrimum novae delineationis opus, / amplissimus et clarissimus / totoque orbe, / a melioribus studiis, literis, libris, / celeberrimus / Erycius Puteanus Bamelrodius, / ubi inspexit, suspexit, / ubi consideravit, depraedicavit; / ac tantopere aestimavit, / ut unum hunc calamum / suo, / cui et aetas nostra similem non vidit, / dignum iudicarit; / quod in elogiis magnorum istorum IV. ducum Burgundiorum, / caesarum Austriacorum / regumque ex eadem augustissima familia Hispanorum / aliorumque archiducum, / tam feliciter ac eleganter praestitit, / ut a curiosioribus ea ocellis expetita / luculento in lucem praelo prodierint. ||

7 Huic autem tanti viri humanitati, / eo maiori quia ultro oblatae, / ut gratum se exhiberet, Horicquius / effigiem eius, usque ad pectus, / ex toto pectore, / una sua linea / tam admirando repraesentavit artificio, / ut comem hunc atque benevolum encomiastem / non modo viventem, sed et docentem / spectatori sisteret. / Quem sui ipsius vultum, gestum, habitum / tam graphice expressos, / hic idem Erycius Puteanus / tanta descripsit energia, / ut nihil doctius, tersius aut venustius queat, / in quadam sua epistola / ad illum data, qui hoc ei simulacrum monogrammum miserat, / quae, quia certo oblectatura est, / pro summa qua scripta est gratia ac lepore, / operae pretium visum fuit / hanc eandem hisce legendam exhibere.

F. 8-18 contain portraits and eulogies of the four Dukes and Mary of Burgundy, as ancestors to the Habsburg rulers over the Southern Netherlands. They are preceded by the Saint Andrew Cross of Burgundy. F. 19-46 contain portraits and eulogies of the thirteen Habsburg Emperors of the Holy Roman Empire, from Rudolph of Habsburg (1218-1291) to Ferdinand III (1608-1657). They are preceded by the lion of the Habsburg and the double-headed eagle of the Holy Roman Empire. 
F. 47-61 contain portraits and eulogies of the four Habsburg Kings of Spain, from Philip the Handsome (1478-1506) to Philip IV (1605-1665), followed by the portraits and eulogies of Balthasar Carlos, Prince of Asturias (1629-1646), Albert VII, Archduke of Austria (1559-1621) and the Cardinal-Infante Ferdinand (1609/10-1641).

F. 62-67 contain various kinds of lineographic drawings, of hunting scenes and others, partly after prints by Jacques Callot (1592-1635).

F. 68-69 Examples of letter types with which the volume ends.

The impression one has when leafing through the volume is that of lack of homogeneity. Even though the drawings, decorative frames, and the calligraphy are from the same hand, one distinguishes three parts which are not really connected: 1 . the main body of the text with dedication and elaborate titles; 2. A small collection of drawings basically related to hunting and dancing; 3. Examples of letter types. The watermarks seem to confirm this impression. The folios bearing the watermark of a double headed eagle are found on the examples of letter types at the end of the volume. We also find this watermark in the Munich copy-book, dated before or in 1633. The same watermark is also found on the folios with the arms of the Habsburg emperors (f. 20), and the eulogy of Maxilimian I (f. 32). The lives of Balthasar, prince of Asturias, and the CardinalInfante, stop in 1638 .

In short, this is a composite manuscript, composed of calligraphic works by Horickius made at different instances. Although the date 1638 appears in the manuscript, the volume must be composed later as is indicated by the inscription at the beginning of the volume. Indeed, it says Horickius has passed away at the time of its composition, leaving a son behind. So the book must have been made after 1643, the year of Horickius' death. The inscription itself was likely made by Puteanus, as he is the author of all the written text in the volume, as we will see. He must have written it before 1646 .

The manuscript's more recent history can be partly reconstructed. It once belonged to Pierre Wouters (1702-1792), former librarian of the Bibliothèque de Bourgogne, the predecessor of the Royal Library of Belgium today. ${ }^{10}$ It thus appears in the catalogue of his collection of prints and drawings published in 1797 on the occasion of the collection's auc-

10 Christiaan Kramm, "Horicke (Baldericus van)", in De Levens en werken der hollandsche en vlaamsche kunstschilders, beeldhouwers, graveurs en bouwmeesters, vol. 3 (Amsterdam, 1859), 750. 
tion. ${ }^{11}$ Wouters was a passionate bibliophile, who made large acquisitions, for the library as well as for himself. The binding probably stems from the late seventeenth century, if not from the first half of the eighteenth century.

\section{Balduinus Horickius}

Baldri(cus) (Baudouin) van Horicke was a calligrapher and writing-master who made his career in Brussels, more specifically at the court of Archdukes Albert $(\dagger 1621)$ and Isabella $(\dagger 1633)$ and of the CardinalInfante Ferdinand of Austria $(\dagger 1641)$, sovereigns and governors of the Southern Low Countries. In 1618 he married Ida Morin with whom he had several children: Martin (1619), Maria (1622), Jean-Christophe (1624), Maria Marguerita (1625), Catherina Anna (1631), and JosephaMaria (1634). The couple first lived at Saints Michel and Gudule, but then moved to Saint Géry and eventually ended up at Saint-Jacques sur Coudenberg. ${ }^{12}$ According to the inscription at the beginning of our manuscript he was in his late sixties when he made the drawings and the writings assembled in the volume. As Horickius died in 1643, he must have been born in the 1570s, rather than around 1600 as stated by Guillo.

So far Horickius has been studied for the collection of melodies and songs he copied and illustrated in fourteen musical manuscripts which have been ascribed to him by Guillo between 2003 and 2018. Furthermore, as we have seen, two copybooks of his hand have been preserved, both dated or datable around 1633. No printed books of his hand are known, which may explain why he has never been studied before Guillo linked his name to the corpus of manuscripts with French, Flemish, Italian, and Spanish melodies and songs for dancing and drinking.

Horickius' copybooks clearly show the influence of, or at least similarity with, the work by his contemporary and very well-known writingmaster, Jan Van de Velde (1568-1623). Van de Velde has unquestionably been the most influential writing-master of the seventeenth century in the Netherlands and this because of his Spieghel der Schrijfkonste, published in Rotterdam in 1605. This copybook was an enormous commercial

11 Catalogue des Estampes et Dessins du Cabinet de M. Pierre Wouters, chanoine de St. Gomer à Lierre et Bibliothécaire de Sa Majesté. Par N.J. 't Sas (Bruxelles, G. Huyghe, Marché aux Fromages, An V), 304. On Wouters see Bibliothèque Royale, Mémorial 1559-1969 (Bruxelles, 1969), 27-31.

12 Guillo 2006 (as in n. 1). 
success and has been translated in many languages. The book is divided into three parts, the first with examples of Dutch, French, German, and English hands, the second part with cursive hands in Latin, Italian, and Spanish, and the third part with his Fondement-Boeck (Book of Fundamentals). This final section offers Van de Velde's treatise on the art of handwriting, a writing manual, teaching how to construct individual letters and words. The book illustrates Van de Velde's particular skill for pennetrekken, or pen flourishes, extending from the text in serpentine loops that evolve into images or designs, often of animals, flowers, or mythological creatures. Pennetrekken constituted an opportunity for the calligrapher to further display his mastery, and Van de Velde was particularly celebrated for his flourishes. We find these flourishes back in van Horicke's copybook.

In the seventeenth century, writing was a skill reserved for the educated class within European society, and calligraphy was considered the tenth Muse. Dutch calligraphers, basically trained schoolmasters, including Van de Velde who was born in Antwerp but practised in Rotterdam, were educated in the South and migrated to the Northern Netherlands to teach at "French schools". ${ }^{13}$ Van de Velde himself taught in Rotterdam at the Latin school. We don't know where van Horicke received his education as a calligrapher, nor do we know if he practised in a Latin or French school. What we do know is that during the reign of the Archdukes and of the Cardinal-Infante he taught the offspring of the courtiers at the Brussels court. Indeed, the Prodigium inscription with which the volume opens, calls him the head of the court schoolmasters and praeceptor palatinus at the time.

If Horickius' style reminds us of Van de Velde's, one particular product of his writing art distinguishes him from his older colleague. Horickius is not only capable of drawing animal or floral designs, and images of mythological creatures, he also draws portraits of men and women and scenes after existing prints using lineography. In the inscription at the beginning of the Prodigium Horickius is praised for this art and it is said his work is unique. Lineography, in French trait de plume, is the

13 B.P.J. Broos, "The 'O' of Rembrandt", Simiolus: Netherlands Quarterly for the History of Art 4 (1971), 150-184, at 151. For an overview of the history of calligraphy from the sixteenth century onwards, and of the many treatises, published or in manuscript, see the website https://pennavolans.com. On Van de Velde: A.R.A. Croiset van Uchelen, Jan van den Velde Schrijfmeester 1569-1623 (Amsterdam, 2005). 
art of drawing without lifting the pen or pencil. It developed in the seventeenth century and would be highly successful, at least until the end of the eighteenth century. According to George Hanton its origin can be traced back to France, but now that Horickius' work has come to the surface again, and because of its exceptional quality, this statement should perhaps be revised. ${ }^{14}$ His virtuous technique can be compared, mutatis mutandis, to the unique technique which the engraver Claude Mellan (1598-1688) developed in the very same years, the late 1630s, in Paris. Instead of creating shade through cross-hatching, Mellan used a system of parallel lines whose breadth and closeness he adapted according to the tone he wanted to obtain. He is known for his portraits, but most famous is his engraving The face of Christ (1649), made from a single, continuous spiralling line that starts from the picture's centre. ${ }^{15}$

\section{Balduinus Horickius versus Berny de Nogent}

We have seen that the Prodigium manuscript belonged to Coella Lindsay Ricketts as part of his calligraphic manuscripts and writing-books collection which the Newberry Library acquired after his death in $1941 .{ }^{16}$ To that same collection can be attributed two more manuscripts from the Horickius corpus established by Guillo: Wing MS ZW 7391.001c, a copybook by Horickius bought by Ricketts from Rimell in London in 1924, no. 38 in the checklist of the Ricketts calligraphy collection acquired by the Newberry Library, and Wing MS ZW 739.B 452, a collection of melodies and songs, bearing no. 39 of that same checklist. In Ricketts's notes, also preserved in the same library, the calligrapher of the latter

14 J. Peignot, Du trait de plume aux contre-écritures (Paris, 1983). I was unable to find G. Hanton, French Lineography (New York, 1927).

15 In 1637 Claude Mellan engraved the pictures of the moon for Pierre Gassendi (1592-1655), the latter being mentioned in the correspondence between Puteanus and Michael Florent van Langren: cf. J.J. Moreau, Honderd veertien Nederlandse brieven van Erycius Puteanus aan de astronoom Michael Florent van Langren (Antwerpen, 1957). On Claude Mellan and his engraving: M. Préaud (ed.), L'Eil d'or. Claude Mellan (1598-1688) (Paris, 1988); J. Sgard, La Sainte Face de Claude Mellan. Étude des bases géométriques du dessin (Abbeville, 1957).

16 It is mentioned in the typed checklist of the collection which dates back to that time: Checklist of the C.L. Ricketts Calligraphy Collection Acquired by the Newberry Library, June 1941. The typescript was compiled by Gertrude Loop Woodward and is now kept in the office of the keeper of the Wing collection of the Newberry Library. 
manuscript is identified as Pierre-Jean-Paul Berny de Nogent (17221779), a self-declared pupil of the famous French calligrapher Louis Rossignol (1694-1739). The identification is based on the similarities with another collection of French, Italian and Dutch songs, described in Magasin Pittoresque 1857, 141, nowadays at the Bibliothèque nationale de France [henceforth $\mathrm{BnF}$ ], ms. KB-88-4, where the identification is maintained on the basis of the same source. Now, the manuscript of the $\mathrm{BnF}$ also belongs to Guillo's Horickius corpus. Without questioning Guillo's identification, his attribution of the manuscript to Horickius deserves some attention. Guillo's identification of the Horickius corpus is based on the correspondences he was able to establish between all these manuscripts as far as their iconography and their content are concerned; the handwriting sometimes varies, but it is basically a bastarda with accompanying flourishes. Of all these manuscripts only three are explicitly signed by Horickius: the Prodigium, Wing MS ZW 7391.001c, and another copybook, already mentioned, dedicated to Duke Wolfgang Wilhelm von Pfalz-Neuburg (1578-1653), now in Munich, Bayerische Staatsbibliothek, Cod. icon. 466. One example may suffice to show the intimate decorative relationship between the manuscripts of the Horickius corpus: the female figure on f. 65 of the Prodigium, drawn after Jacques Callot's Lavinia (Fig. 2, see infra), corresponds to the figure of manuscripts Blankenburg 125 and 126 (resp. images 10 and 12 of the online reproduction) of Wolfenbüttel, and of the drawing on f. 8 of MS ZW $7391.001 \mathrm{c} .{ }^{17}$ However, the Magasin Pittoresque has put forward a very strong argument in favour of its identification of the calligrapher as Berny de Nogent. The latter published in his copybook Atlas de portraits et figures de traits et entrelacs à la plume. Ouvrage unique en ce genre dédié aux amateurs (Francfort: [s. n.], engraved by J.C. Back, 1761; Paris, BnF, EST 437) a print which bears the following title and signature: Paul Rubens et sa première femme. Inventé, et fait à la plume par le chevalier de Berny. According to a manuscript note on $\mathrm{f} .3$ of Paris, $\mathrm{BnF}, 4-\mathrm{KB}-88$, a drawing of the same subject must have been part of the manuscript. This may explain why the manuscript has received the following title in the online catalogue: [Recueil composite de chansons françaises, italiennes et hollandaises calligraphiées et de figures

17 Complete concordances between all manuscripts of the corpus can be found in Guillo 2006 (as in n. 1). For an image of Callot's print, see Guillo 2018 (as in n. 1), fig. 5. 
dessinées à la plume d'après Rubens]. ${ }^{18}$ Another manuscript copy of the same portrait, albeit slightly different in execution, can be found in Brussels, Royal Library of Belgium, ms. Mus II 5139. How are we to understand this contradiction between the homogeneity of the Horickius corpus and the signature of Berny de Nogent on a print of a drawing we find in some manuscripts of that corpus? The only plausible explanation must be that Berny de Nogent imitated Horickius' drawings and sold them as being his own invention. The question is then: from where did he get these drawings which were never printed and have come to us thanks to their insertion into the musical manuscripts studied by Guillo? What we know about the life of Berny de Nogent we owe to the research carried out by Victor Advielle in the nineteenth century. ${ }^{19}$ From this work can be inferred that information from Berny himself can hardly be trusted. In a manuscript of portraits of 1765 he calls himself Chevalier romain et de Saint-Michel de Cologne, ancien commis du Trésor royal, et premier des bureaux des Armées du Roy en Allemagne, Maître de l'Académie des Sciences et Arts de Bruxelles, Strasbourg et Metz - all of these are titles and functions for which no documentary proof could be found that they were actually bestowed on Berny or that they even existed. ${ }^{20}$ What seems certain, though, is that he made his career in the army before dedicating himself to the art of calligraphy. In 1757 he lived in Brussels, three years later we find him in Bonn, but in 1763 he was back in Brussels where he wrote his Emblêmes et Devises. It is during his Brussels sojourn of the 1750s that he must have had access to Horickius' writings, perhaps through Pierre Wouters, the librarian of the Bibliothèque de Bourgogne, then kept in the buildings of the Palais Isabelle or Maison des arbalétriers (House of the Arbalists) in the rue d'Isabelle. Berny's plagiarism is a clear testimony to Horickius' art and influence reaching far into the eighteenth century.

18 Cf. https://gallica.bnf.fr/ark:/12148/btv1b10548943f.

19 V. Advielle, "Notice sur le chevalier de Berny, dessinateur et calligraphe du dix-huitième siècle", in Réunion des sociétés des beaux-arts des départements, salle de l'hémicycle, à l'École des beaux-arts à Paris, du 20 au 24 avril 1897 (Paris, 1897), 172-187.

20 Paris, BnF, ms. 4-KB-88 (A): Portraits de plusieurs princes formés de traits de plume, ouvrage unique en son genre; Les Empereurs romains, \& autres Rois \& Princes; Portraits d' hommes illustres formés de traits de plume, ouvrage unique en son genre; Portraits figurés, oiseaux et fleurs de traits et traits de plume, 1565. 


\section{Balduinus Horickius and Pedro Diaz Morante}

Guillo was able to identify several prints that served as a model for Horickius' drawings: fourteen drawings made after Jacques Callot, Pierre Mariette, Jeremias Falck, Jean I Le Blond, Balthasar Moncornet, Michel Lasne, Pierre Daret, and others. ${ }^{21}$ As for the equestrian portraits in the Prodigium, no precise source has yet been found, but an interesting connection can be made here with the work of another famous calligrapher and writing-master, this time from Spain: Pedro Diaz Morante $(1665 / 6-1636){ }^{22}$

Diaz Morante, also known under the name Morante, is the author of a very influential and innovative writing-book which revolutionized the teaching of calligraphy in Spain and elsewhere. Essential to the new technique promoted by Morante's manual was the fact that the letters of his bastarda were systematically linked to one another, which made writing (and its learning) less time-consuming, without losing its elegance and readability, as Gothic cursive at the time tended to do. Morante's work Arte de escrivir inventada comes fabor de Dios... was published in four copper engraved parts $(1615,1624,1627$, and 1630); a fifth part was probably published at different moments, in single woodcuts. We find here some designs which clearly go back to Van de Velde's work. ${ }^{23}$ Besides the five parts, some independent prints were published, which were sometimes included in one of the fore-mentioned parts of Morante's writing-book. ${ }^{24}$ One of these independent sheets represents, in two different versions, the equestrian portrait of Philip IV of Spain, similar if not identical to the latter's portrait in Horickius' Prodigium (fig. 3). Both seem to be inspired by the equestrian statue of the king on the Plaza de Oriente in Madrid. ${ }^{25}$ The statue (1634-1640) is made by Pietro Tacco (1577-1640), pupil and successor of Giambologna (1529-1608). The

21 Cf. Guillo 2006 (as in n. 1); for pictures, see Guillo 2018 (as in n. 1). I thank Laurent Guillo for an update of the artists he identified.

22 Emilio Cotarelo y Mori, Diccionario biográfico y bibliográfico de calígrafos españoles, vol. 2 (Madrid, 1916, no. 745) for what follows on Diaz Morante's life and work. In part 5, though, of Newberry Library, MS Wing ZW 640 M792, containing a collection of loose sheets of Diaz Morante's writingbook (for which see infra), there is a print dated 1639, three years after the author's presumed death. The print is described in Cotarelo y Mori 1916, 57, as an independent print.

23 Cotarelo y Mori 1916, 57.

24 Cotarelo y Mori 1916, 76. I have consulted the copy of the Newberry Library, Wing ZW 640 M792.

25 Cf., for the Morante print, Cotarelo y Mori 1916, 76. 
latter is also the author of another equestrian statue, of Philip III on the Plaza Mayor in Madrid, which was finished by the same Tacca in 1616. The statue of Philip IV is said to be made after a design by Velasquez and perhaps following the iconography of Rubens.

In 1616 Morante became official examiner of teachers of calligraphy in Madrid and in 1618 master of writing to the son of Philip III of Spain, the soon to become Cardinal-Infante Ferdinand, who as governor of the Southern Low Countries, where he arrived in 1634, would take Horickius in his service. ${ }^{26}$ As his biographer states that Diaz Morante died in Madrid in 1636, he probably never made it to the governor's court in Brussels, and thus never met Horickius, nor saw his work. But even without being able to establish with certainty the kind of relationship that must have existed between both calligraphers, it is clear that in the first half of the 1630s the Brussels court favoured the flourishing calligraphy represented by Horickius and Morante, and must have been acquainted with their lineographic portraits and scenes after prints. Even more so, their portraits drawn "au trait de plume" would constitute a source of inspiration to other calligraphers as late as the second half of the eighteenth century with Berny de Nogent as their most flagrant imitator. ${ }^{27}$

\section{Balduinus Horickius and Erycius Puteanus}

Puteanus discovers Horickius' art somewhere in 1638, the same year in which some drawings as well as Puteanus' eulogies of the Prodigium are made. At the time, archduchess Isabella had passed away five years already, and the Cardinal-Infante had been in the Southern Netherlands for about four years.

26 Cotarelo y Mori 1916, 50-51.

27 For chronological reasons and on the basis of the following eulogy by the poet José de Valdivielso (1565-1638), chaplain of the Cardinal-Infante, published in the third part of Diaz-Morante's writing-book, one is inclined to think that Morante influenced Horickius in making his portraits of men and women after prints: "Cuyas ejecuciones, como á los mios, repetidas veces, has llamado á los ojos por jueces, en sus lineas bebiendo suspensiones; pues que con ambas manos á un mismo tiempo, sin cobrar aliento, remedas con amagos soberanos aves corriendo el viento, peces las aguas, y los campos, brutos; plantas ricas de flores y de frutos. Y lo que es mas, tu mismo es bien te asombres á lazos formas de mujeres y hombres, viveza y hermosura, helada suspensión de la pintura, con silenzio estupendo, y dudas cuerdas de lo que esta viendo." 
Puteanus' friend William Van Blitterswyck, whose family arms are drawn at the beginning of the Prodigium, has sent him a portrait which Horickius made of the humanist by using lineography. As far as I can tell, the portrait is not preserved but it must be the same portrait which is mentioned in the inscription with which the Prodigium opens. Puteanus is very pleased with the result and dedicates a whole letter to the technique's appraisal:

Accepi vero, mi Blitterswycki, imaginem meam, et ingeniosam Horiquii manum admiratus sum: scribentis an pingentis? Hic profecto calamus praestat, quod alibi penicillus; hic lineae, quod alibi colores. Lineae? Imo linea, quam unam et omnem possum appellare, vere aeternam, sine principio, sine fine. A linea olim pictura coepit, redit ad lineam, et picturam superat. Hoc tandem Horiquius potuit, una complexus linea, complexus maeandro, ut antiqui appellabant, quicquid omnes pingunt, una longitudine admirando flexu circumducta omne latitudinis spatium. In compendio ambages cerno, in ambagibus compendium. Gyri sunt, vertigines, euripi, et a novo Daedalo labyrinthus nova arte exstructus. Error ubique est, et certum tamen vestigium, quod cum sequor et elabi studeo, vere me inclusum deprehendo. Si philosophari velim, hic me ipsum video, et velut $\mu \varepsilon v o ́ \gamma \rho \alpha \mu \mu$ ov [sic] repraesentari. Caput, linea est; crines et barba, linea; corpus et vestis, linea, quae nunc recto simplicique sulco extenditur, nunc sinuoso ductu recurrit, nunc in spiras volvitur, nunc in circulos rotundatur, nunc in annulos et quasi cincinnos calamistratur, nunc in angulos acuitur, nunc emblemate, tanquam opus tessellatum, vermiculatur. Ad summam, nihil nisi lineam invenio, et laboriosa tamen arte ornatus incedo; nihil nisi lineam, et lineamenta impleta sunt. Non jam miror margaritarum lineam a bonis scriptoribus nominari, noster expressit; formidinem in ferarum venatione dici, sive $\delta \varepsilon \tilde{i} \mu \alpha$ $\pi \mathrm{o} \lambda \hat{\chi} \chi 0 o v$, noster non colorum, sed flexuum varietate ipsos homines capit. Ultimam rerum lineam mortem esse noster suam et sic primam esse vitam ostendit. Sed quot litteris, verbis, lineis opus ut unam et Horiquianam describam? Ille me ornare voluit, ille suum facere, ille vivere linea sua; quam gratiam referam? Dum rationes excutio, dum vires meas expendo, agnoscam saltem totam una linea et ab uno Horiquio naturam, non adumbrari, et distingui, non colorari et ostendi. Sed quemadmodum, te hortante, specimen artis suae in imagine mea dedit, ita urge, si me amas, ut translata ad bis 
duodecim Caesares, partim Romanos, partim Austriacos, lineari industria, publicum miraculi auspicium ab augustissimo argumento desumat. Digni hi inter omnes sunt, qui ab uno Horiquio, velut novo Philocle Aegyptio, vel Cleanthe Corinthio [Plin. M. NH 35.5], primis linearis picturae inventoribus, lineentur; dignus Horiquius, qui hos omnes unus lineet. Vale, mi Blitterswycki, et quia me amas, elegantias omnes amare perge; quia elegantias, me. Lovanii, in Arce, Eidibus Maii M.DC.XXXVIII. ${ }^{28}$

This letter is again without doubt the one to which the inscription in our volume is referring, as it repeats some of its ideas and words. Except for the very detailed and precise description of lineographic practice, three more particulars can be gathered. First, Puteanus uses Pliny's Natural history to trace the origins of lineography back to the Greeks, where it is said to be at the origin of painting as such. In so doing, he equals Horickius' art to painting. Secondly, Puteanus considers Horickius' work to be unique and not to be found elsewhere. Obviously, he was not informed about Morante's work. Thirdly, the letter informs us that it was Puteanus' portrait by Horickius that inspired our humanist to make a gallery of similar portraits of twelve German and twelve Austrian emperors, a project which would eventually produce the Prodigium.

\section{Erycius Puteanus and Paolo Giovio}

If Puteanus' project to write a portrait gallery of the Dukes of Burgundy and the Habsburg Kings and Emperors, as we find it today in the Prodigium, must date from his encounter with Horickius' lineographic work, the idea of illustrated eulogies goes way back. Already in the mid-1620s Puteanus mentions this in some of his letters. ${ }^{29}$ Also, the project could

28 Epistolarum apparatus posthumus, Centuria III, ep. 55, 92-94.

29 See his letter to Claudius Balanconius, published in his Podium Philippicum, Philippos Hispaniarum et Indiarum monarchas elogiis historicis repraesentans. Pars theatri heroici (Bruxellae, ex officina Mommartiana, 1643), a work I will return to later on: "Inter illustrium virorum imagines, nisi et tuam habeam, tuam videar et nobilitatem et virtutem et dignitatem ignorare [...]. Ante omnia igitur heroicum vultum tuum, coloribus expressum ambio, quem mox quidem epigrammate, deinde elogio, denique pleniori scriptione venerer [...]. Lovanii, in Arce, prid. Non. Ian. MDCXXIV." See also his letter to Libert Trenodiclaeus published in Eryci Puteani Epistolarum selectarum apparatus miscellaneus, et novus, officia familiaria, negotia, studia continens 
have been initially inspired by Puteanus' participation in Francart's print of the Pompa funebris for Archduke Albert of Austria in 1622-1623, for which he delivered part of the text based on his own Phoenix principum: sive Alberti Pii morientis vita (Lovanii, apud Henricum Hastenium et Petrum Zangrium, 1622). ${ }^{30}$ From the very beginning, the model for his own portrait gallery was the Museum by Paolo Giovio (1483-1552). Puteanus repeats this several times over the years in his correspondence with fellow humanists, friends as well as officials. ${ }^{31}$

Paolo Giovio's Elogia virorum bellica virtute illustrium veris imaginibus supposita, quae apud Musaeum spectantur, as the work's full title states, was a collection of inscriptions (elogium in its classical sense of subscription and not of eulogy) of important men destined to accompany, to "illustrate", their real portraits which Giovio had collected in his villa at lake Como. ${ }^{32}$ Originally planned in four volumes (1. authors of the past; 2. authors of the present; 3. artists; 4. popes, kings and military leaders) only two would actually be published.

To understand the complex story of the Elogia's production, in particular the relationship between text and image, to which I will return later on, it is worthwhile to briefly recall the publication history of Giovio's Museum, which has been Puteanus' source of inspiration. Giovio's elogia of literate men of the past appeared in 1546. At the end was added a list of living authors, from Pietro Bembo (1470-1547) to Basilio Zanchi (1551-1558), whose portraits Giovio had already in his possession. It was

(Amstelodami, apud Iodocum Ianssonium, 1647), Centuria III, ep. 58, 65: "Nunc collegi denuo vires, imo animos, paratus, Iovii exemplo, virorum illustrium Elogia condere, quae imaginibus ipsis animentur [...]. Lovan. in Acropoli, prid. Eid. Maii M.DC.XXIV."

30 On Jacques Francart (1582-1651) and his Pompa funebris, see J. Papy, "Tears old and new: Erycius Puteanus, Philippe and Jean-Jacques Chifflet and the Lacrymae prisco ritu fusae for Archduke Albert", Humanistica Lovaniensia 52 (2003), 217-236 (217-219).

31 Cf. the passage of the letter to Libert Trenodiclaeus quoted in n. 29.

32 On Giovio's Museum and in particular on the history of its edition, see M. Gianoncelli, L'antico Museo di P. Giovio in Borgovico (Como, 1977); R. Meregazzi (ed.), Pauli Iovii, Elogia virorum illustrium curante R.M.: Gli elogi degli uomini illustri (Rome, 1972), 1-21; P.O. Rave, "Das Musee Giovio zu Como", in Miscellanea Bibliothecae Hertzianae (München, 1961), 275-84; E. Müntz, "Le Musée de portraits de Paul Jove. Contributions pour servir à l'iconographie du Moyen Âge et de la Renaissance", Mémoires de l'Académie des Inscriptions et Belles-Lettres 36.2 (1901), 249-343. For a recent edition, see K. Gouwens (ed.), Paolo Giovio, Notable men and women of our time (Cambridge MA - London, 2013). 
published in Venice with Michele Tramezzino, bearing the generic title already mentioned, which was supposed to be the title of the whole project. ${ }^{33}$ The edition offers no images and in his dedication to Ottavio Farnese, prefect of the city of Rome, Giovio explains why that is. ${ }^{34}$ His dedicatee has asked for the images of illustrious men from his collection of portraits kept in his villa at lake Como, in the form of elogia, as it was not possible to produce small pictures, because of the time that would take and the difficulty of such an enterprise. The elogia indeed consist of the inscriptions originally written on pieces of parchment hung beneath the portraits themselves. They focus on the hero's virtues so that the reader, or Farnese himself as Giovio's translator Lodovico Domenichi has it, can judge and delight in them. ${ }^{35}$ To the author of the elogia, though, reading about the heroes' virtues seems more appropriate than senseless gazing for a while at their beautiful pictures. Five years after the first publication, in 1551, a volume on military leaders followed, in seven books: Pauli Iovii Novocomensis episcopi Nucerini Elogia virorum bellica virtute illustrium veris imaginibus supposita, quae apud Musaeum spectantur (Florentiae, in officina Laurentii Torrentini ducalis typographi, 1551). Again, the edition has no pictures. In his preface to Cosimo dei

33 Meregazzi 1972 (as in n. 32), 17.

34 On the relationship between image and text in Giovio's Museum see S. Maffei, "Lo spazio delle parole. Gli Elogia e il Museo di Paolo Giovio tra innovazione e tradizione", in S. Maffei, F. Minonzio and C. Sodini (ed.), Sperimentalismo e dimensione europea della cultura di Paolo Giovio. Atti del Convegno (Como, 20 Dicembre 2002) (Como, 2007), 9-29 (15-19 and 26-28).

35 Le iscrittioni poste sotto le vere imagini de gli huomini famosi in lettere, di Mons. Paolo Giovio Vescovo di Nocera. Tradotte di latino in volgare da Hippolito Orio Ferrarese (In Venetia, appresso Giovanni de' Rossi, 1558), f. A4v: "Ma sopra tutto mostrate desiderar quelle imagini de gli huomini famosi, le quali sono nel mio Museo al lago di Como, dono veramente dilettevole insieme et utile molto. Et perché non si potrieno senno' con lunga et malagevole fatica ritrar dal vero in piccioli quadretti o medaglie, volete ch'in parole io vi mandi i ritratti delle virtù loro, che me le chiedete per inscrittioni, acció l'alte doti di tanti eccellenti ingegni descritte con lo stile passino al giudicio dell' animo vostro con una varietà mirabile, et con un non so che di più nobile et più soave diletto, percioché vi pare cosa assai più grave, più bella et che più alla maraviglia risguardi il leggere le virtù di quegli animi grandi descritte con le proprie lodi loro, che il vedere le effigie d'essi con ogni diligenza ritratte dal naturale, anchora ch'io so' certo da gli occhi vostri sariano state mirate con un piacere non mediocre; ma vano peró et di nessun momento." For the Latin, I consulted the volume published posthumously in 1561 in Basle: Elogia doctorum virorum ab avorum memoria publicatis ingenii monumentis illustrium authore Paulo Iovio Novocomense episcopo Nucerino (Basileae, [1561]), 1-2. 
Medici, the hero to whom Giovio dedicates this second volume on illustrious men, gives no explanation whatsoever on the absence of images. Instead, he elaborates on the idea of Gloria, that pushes men to do good deeds. The lives of his heroes illustrate the different ways to achieve glory and may encourage others to pursue in one way or another the same goal.

Both publications, deprived of any illustration, serve as a kind of visitor's guidebook to Giovio's collection of portraits in his villa at Borgovico. This is made evident in expressions like "cum ex hac imagine verissima" in the description of Bajazet II in the fourth book (189). In the villa itself, as we have seen, pieces of parchment with the inscription hung beneath every portrait. ${ }^{36}$ In the same way, in a letter to his brother Benedetto of 1545, Giovio writes that he is finishing the "Elogia clarissimorum virorum, quorum imagines apud Museum visitantur". ${ }^{37}$ In conclusion, for Giovio, to reach his goal, text is far more effective than image, although he would have liked very much an illustrated edition of his elogia, if materially it would have been possible for him. ${ }^{38}$

Giovio's initial wish will be realized posthumously. In 1575 Peter Perna of Basle publishes the first illustrated edition of Giovio's Museum: Pauli Iovii Novocomensis Elogia virorum bellica virtute illustrium, septem libris iam olim ab authore comprehensa et nunc ex eiusdem Musaeo ad vivum expressis imaginibus exornata (Petri Pernae typographi Basil. opera ac studio, 1575). It is dedicated to Francesco de' Medici, Duke of Tuscany and son of the first dedicatee of Giovio's book on military leaders. There is no explanation as to why the prints were added. In 1577 another illustrated edition, this time in octavo, is published by the same editor entitled Musaei Ioviani imagines Artifice manu ad vivum expressae nec minore industria Theodbaldi Mulleri Marpurgensis musis illustratae (Basileae, ex officina Petri Pernae, 1577). Besides the prints, engraved by

36 Almost the same words are used by the author in his letter to Daniello Barbaro (1513-1570): Opera, vol. 2 (Roma, 1958), 4.

37 Quoted by Meregazzi 1972 (as in n. 32), 14.

38 See his letter to Doni of 1548: "E volesse Dio che di questa maniera si potessero intagliare tutte le immagini, ch'io tengo al Museo, almanco quelle degli uomini famosi in guerra, a i quali ho cominciato a far gli Elogi, e anderanno presto in stampa. Né io desidererei altro, se non che si potessero imprimere le loro immagini un poco più grandette delle medaglie antiche, e aiutarle poi con qualche colore per maggior dignità; il che quando succedesse no' crederei che dagli Antichi in qua fosse uscito il più vago libretto. E se di qua posso cosa alcuna, valetevi di me con ogni sicurtà." (Giovanni Bottari, Raccolta di Lettere sulla pittura, scultura ed architettura, vol. 5 [Roma, 1766], 96). 
Theobald Müller and identical to those of the 1575 edition but in different frames, the edition has replaced Giovio's eulogies by poems of 3 distichs, equally of Müller's hand. This time a dedication letter by the same Müller to Louis IV, Landgrave of Hesse (1537-1604), whose father's portrait (Philippus Hessorum princeps) has been added to introduce Giovio's list, goes further into the matter of illustrating Giovio's work. ${ }^{39}$ The text reads as if he is contradicting Giovio's words quoted above: Antiquity has always celebrated its famous men not only through books but also through their images, because images activate the visual memory of those who passed away and bring them back to life. Therefore the libraries were decorated with portraits and sculptures, in order to transmit to posterity not only the memory of those illustrious men but also their image. In this way Asinius Pollio, founder of the first public library in Rome, offered the public images of deceased authors whose works were stored in the library, making one exception, in the case of the encyclopedist Varro who at the time was still alive. The latter had glorified so many illustrious men through his numerous works, in which he had inserted over 700 images, that he deserved the same glory already during his lifetime. The same merging of text and image Müller has decided to offer his dedicatee in his edition of Giovio's work, combining the arts of printing and engraving. To Müller, in the case of Giovio's Museum, the art of engraving has rendered its services to printing, his sister art, so that the pleasure we experience as readers of the lives of heroes is doubled by looking at their images. ${ }^{40}$

39 Tobias Stimmer is the engraver of the portraits of the 1575 edition, according to J.B. Thacher, Christopher Columbus: his life, his works, his remains: as revealed by original printed and manuscript records, together with an essay on Peter Martyr of Anghera and Bartolomé de las Casas, the first historians of America (New York - London, 1904), 16.

40 "Statuae profecto et imagines ob idipsum quod diu durant praesentique inspectione non memoriam tantum absentium refricare, sed et palingenesiam quandam opticam defunctorum repraesentare videntur, primum sibi locum vendicare merito possunt. Asinius Pollio, qui Romae primus ex manubiis bibliothecam publicavit primusque ingenia hominum rem publicam fecit, imagines etiam doctorum, qui iam fatis concessissent et inter eas singulari Gloria unius M. Varronis viventis (ut qui innumeris voluminibus de omni genere literarum optime meritus esset, iisdemque clarissimorum virorum supra septingentas imagines inseruisset, ea quam mortuis dederat gloria, vivus quoque perfrueretur) ibidem spectandas proposuit. [...] Cum igitur antiqui in hoc studium certatim incubuerint, ut vel dignitate vel virtute illustrium virorum non memoriam tantum, sed veras insuper effigies ad posteros transmitterent, ne hac quidem in parte nostrum illis cesserit seculum, quo inter omnes artes mechanicas 
Finally, in the illustrated two-volume edition of $1577-1578$ by Peter Perna, containing Giovio's portraits of the twelve viscounts of Milan, of Alfonso d'Este of Ferrara (1476-1534), of Gonzalo Fernandez de Cordoba (1453-1515), of Fernando Francesco d'Avalos, marquis of Ferrara (1489-1525), of Popes Leo X (1475-1521) and Hadrian VI (1459-1523), as well as of Cardinal Pompeo Colonna (1479-1532), the editor addresses in his letter to Margraves Ernest-Frederick of Baden-Durlach (15601604) and James III of Baden-Hachberg (1562-1590), published at the beginning of the volume, the collaboration between authors and print makers serving the same goal, that is saving from oblivion the memory of glorious deeds, the first by writing them down, the second by confronting the reader with an image of the hero's physics (corporum lineamenta). ${ }^{41}$

maxime liberalis graphice sorori suae typographicae suam sic locat operam, ut et res praeclare gestas magno cum fructu legere et eorum, a quibus sunt gestae, vivas imagines geminata cum voluptate, cum memoriae tum artis spectare queamus. Eius sane industriae inter multa alia, hoc etiam in praesens specimen luculentissimum exhibere et principi viro eidemque non modo doctorum hominum patrono, sed et doctrina excellente praedito, hasce virorum dignitate inprimis (quam gloria litterarum armorumve in suo quique genere conspicuam reddidere) illustrium, ex Musaeo Ioviano fere ad vivum expressas imagines consecrare voluimus: ut heroes illi sibi ipsis non magis de palingenesia hacce graphica et typographica quam quod sub tam illustri patrocinio vitam receperint, (si quis horum sensus mortuis inesset) merito congratulari possint [...]. At ex hac vel Ioviana bibliotheca, vel nostro etiam chartophylacio, clarissimorum nostri seculi luminum atque columinum, in universum orbem Christianum, sive celebritatem nominis eorundem, sive pectoris fidam spectemus industriam, novae veluti coloniae poeticae (si modo pictura est muta poesis) citra negotium atque sumptum deduci poterunt [...].” Müller, Musaei Ioviani imagines, f. 25v.

${ }_{41}$ Pauli Iovii Novocomensis episcopi Nucerini Vitae illustrium virorum tomis duobus comprehensae et propriis imaginibus illustratae (Basileae, Petri Pernae typographi, 1578), f. 2v-3r: "Quid vero, si literis doctorum hominum res consignatae et inscriptae, tamen a luce populari, hominumque conspectu peregrinentur? Omnem enim tum etiam gloriam necesse est iacere, oppressam tenebris et caligine noctis obscuratam. Itaque in pulcherrimam consiliorum rationem ingredi videntur, tum qui res gloriosas eruditis literis complectuntur, tum qui eas ante hominum propositas conspectum, proferunt in lucem, et typorum atque imaginum ornamentis tanquam novis et magnis adiumentis ad librorum perpetuitatem expoliunt. Quae me etiam causa incitavit, ut cum antea plurimos illius generis pulcherrimos sane et clarissimos authores luce ornassem, eundem nunc cultum Iovii libris tribuerem, quos de vita excellentium virorum scriptos reliquit. Et eos antea saepe excusos denuo recuderem, luminibus typorum et imaginum artificiose fabrefactarum clarissime illustratos, in quibus non solum virtutum et gloriae effigies a Iovii ingenio expressae, sed corporum etiam ducta affabre singulari artificio lineamenta conspicerentur, quod existimavi non 
So, when Puteanus writes on several occasions in his letters that Giovio's Museum has been his source of inspiration for his own portrait gallery, this must have had its importance. As a matter of fact, he very well may have been inspired by Giovio's explicit call for help in completing his portrait gallery especially with images of non-Italians. ${ }^{42}$ We cannot tell which edition Puteanus actually leafed through, but the question if it was an illustrated edition or not, is perhaps worth trying to answer. ${ }^{43}$ Portrait galleries, illustrated or not, can already be found in classical literature. Varro has already been mentioned; we can add Cornelius Nepos' De viris illustribus or Suetonius' Vitae duodecim Caesarum. In the Renaissance, they proliferate, in imitation of their classical forerunners, from Francesco Petrarca's and Boccaccio's De viris illustribus, over Fulvio Orsini's Imagines et elogia virorum illustrium et eruditorum to Giorgio Vasari's Vite. Illustrations are drawn from different sources, but numismatics are clearly one of the privileged sources. In the Netherlands, editions of these galleries circulated widely, but also new initiatives were published. To quote but a few of these portrait galleries published at the end of the sixteenth century or in the very early seventeenth century, that Puteanus must have known: besides the famous Schilder-boeck by Karel Van Mander (1604), I should mention Hieronymus Cock's edition of Lampsonius' selection of portraits of Flemish artists, clearly inspired by Vasari's Lives. Yet, the inscriptions are rather short, limited as they are to a maximum of ten lines, often addressing directly the picture itself. Still in 1572 Philip Galle publishes his Virorum doctorum de disciplinis bene merentium effigies XLIIII. The book was a commercial success and was re-edited in 1587 (enriched with fifty more portraits), 1595 and 1606. This time, its model clearly was Giovio's Museum, albeit a version in which the inscription had been reduced to a poetic eulogy in distichs, like Müller's edition of Giovio's work. It is remarkable that Puteanus does not mention these works and instead deliberately chooses to follow the example of Paolo Giovio. What is it that he prefers in Giovio's work?

exiguum pondus habere ad libri, et inde ad authoris atque omnium qui libro continentur, perennem aeternamque memoriam."

42 Meregazzi 1972 (as in n. 32), 147 (f. 78r): "Sed qua spe alienae benignitatis munus expectaverim, quum haec nostra cupiditas ad externorum imagines extendatur, nisi viros nobiles adiutent honestisque votis arrideant. Rogabo itaque veteres patronos in provinciis dignitate atque opibus praecellentes [...] ut hoc officium expedite ac liberaliter praestare velint."

43 What follows is based on the reading of T. Casini, Ritratti parlanti. Collezionismo e biografie illustrate nei secoli XVI e XVII (Firenze, 2004). 
Could it be the predominant role of the text in the first editions? Or the relationship between text and image in the later editions? When he first mentions Giovio's work in the context of writing contemporary eulogies, so we have seen (supra, 18), he defines Giovio's work as that of a historian. He does not explicitly speak of illustrations nor of images, but writes he wants to express in colours the dedicatee's heroic face. Four months later, in another letter, he mentions Giovio's work again, this time with clear reference to the illustrations: he will write eulogies that will be enlivened thanks to images. Almost ten years later, in a letter to Gerard Vossius (1577-1649), in which he announces the will to open up his portrait gallery to other royals, after the example of Giovio's Museum, which he once visited, he mentions his decision to add illustrations as a way to enhance its value. ${ }^{44}$

Puteanus' visit to Como goes without doubt back to his Italian years (1597-1606), most likely when he was in Milan in the early years of the seventeenth century, in the service of Cardinal Federico Borromeo (15641631), who, after Giovio's example, created his own iconographic gallery. ${ }^{45}$ Puteanus' idea of a por-trait gallery may thus even have arisen already during his sojourn in Milan. ${ }^{46}$

44 Epistolarum apparatus posthumus, Centuria III, ep. 69, 117-120 (119). The text is cited infra, n. 58 .

45 Casini 2004 (as in n. 43), 115. See also P. Vanoli, "Il conoscitore e il cardinale: Girolamo Borsieri e Federico Borromeo (con una nota sui ritratti giovani)", in A. Roca, A. Rovetta and A. Squizzato (ed.), La donazione della raccolta d'arte de Federico Borromeo all'Ambrosiana 1618-2018. Confronti e prospettive (Milano, 2019), 411-419 (414-416) and Id., Il 'libro di lettere' di Girolamo Borsieri: arte antica e moderna nella Lombardia di primo Seicento (Milano, 2015), 46. On Puteanus' Italian years see R. Ferro, Federico Borromeo ed Ericio Puteano. Cultura e letteratura a Milano agli inizi del Seicento (Roma Milano, 2007).

46 See, for instance, his letter to Giovanni Battista Sacco of 1600 where he calls the bibliophile Gianvincenzo Pinelli (1535-1601) "alterum Iovium in clarorum virorum imaginibus colligendis": Epistolarum fercula secunda [Hanoviae, typis Wechelianis, apud Claudium Marnium et heredes Ioan. Aubrii, 1603], ep. 42, 74. In the 1615 edition of his oration De rhetoribus et scholis palatinis Mediolanensium, Puteanus refers to Giovio's Elogia when discussing illustrious humanists of the fifteenth and sixteenth centuries in Milan, in Erycii Puteani Suada Attica, sive orationum selectarum syntagma (...) (Lovanii, typis Io. Chrisoph. Flavii, 1615), 73. The reference is not in the work's 1603 edition: cf. Ferro 2007 [as in n. 45], 158-159. 


\section{Erycius Puteanus and William Blitterswyck}

As Wing MS ZW 6465 .H782 bears the arms of William Blitterswyck (Brussels, ca 1600 - Mechelen 1680), the manuscript must have been made for him or at least at his request. Blitterswyck was an intimate of Puteanus; their extensive correspondence testifies to their long friendship. $\mathrm{He}$ is the author of Dissertationes de rebus publicis, which apparently have not been preserved, and of distichs on the fire that destroyed Rurmond in 1665 and on its rebuilding the year after, which are preceded by the city's historical description. ${ }^{47} \mathrm{He}$ also translated a work on political principles by Diego de Saavedra, which had several editions. ${ }^{48}$ Finally, he added Latin verses in a book on Notre-Dame de Montaigu. ${ }^{49}$ Roman Montero de Espinosa (1620-1664) dedicated to him his La amazona del norte, Christina, reyna de Suezia, Gotia, Vandalia, etc. ${ }^{50}$ Starting his career as magistrate of the city of Brussels, he became in 1643 counsellor at the court of Ghelder and in 1659 member of the Great

47 Ruraemunda vigens, ardens, renascens, sanctissimo domino nostro Alexandro VII, pontifici opt. Max. totius virtutis ac pietatis thesauro, pro sua in eam, eiusque zelosissimum antistitem, illustrissimae prosapiae virum Eugenium Albertum d'Allamontium, miseratione, ac munificentia, ad exiguum tanti solatii, vere paterni, ac subsidii prorsus opportuni hostimentum, iure meritissimo cultuque demississimo consecrata a G[uilelmo] D[e] B[litterswyck] C[onsilario] R[egio] (Bruxellæ, typis Guilelmi Scheybels, 1666). Cf. the online version: https://books.google.com/books?id=169bAAAAQAAJ\&pg=PP13\&dq=ruraemun da\&hl=fr\&sa $=X \& v e d=0 a h U K E w j 814 T$ guPrgAhVn34MKHQT3CYQQ6AEIKT

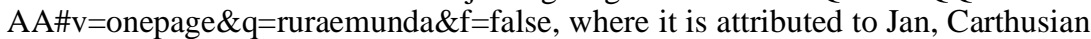
in Bruges (1606-1666). On Blitterswyck see J. Delecourt, "Blitterswyck, Guillaume Van" in Biographie nationale de Belgique, vol. 2 (Bruxelles, 1868), 481-482.

48 Idea principis christiano-politici centum symbolis expressa a Didaco Saavedra Faxardo, equite, cum gratia et privilegio ad novennium (Bruxellae, excudebat Ioannes Mommartius, suis et Francisci Vivieni sumptibus, 1640).

49 Oratio panegyrica habita in sacra aede B. Mariae Aspricollensis: tres inscriptiones quibus G.D.B(litterswyck) anno MDCLV, inter alia plura letitiae publicae Schemata ac Parerga, adornavit festivitatem Ruremundensem, ob felicem prorsus ac toti orbi christiano salutarem magni ac eminentissimi Fabii Chisii ad summum pontificatum assumptionem solemniter institutam. Cum metris et applausibus panegyricis (Mechliniae, ex officina Ioannis Iaye, 1663).

50 La amazona del norte, Christina, reyna de Suezia, Gotia, Vandalia, etc. Dedicada y ofrecida a la veneracion afectuosa de D. Guillermo de Blitterswyck [...] Por D. Panphilio de Ogava (Ruremunda, en la Enprenta de Gaspar du Pree, 1654). 
Council of Mechelen. He was also Libellorum supplicum domus regiae magister, the king's Master of Requests. ${ }^{51}$

We have seen that the idea of a portrait gallery of famous men illustrated by Horickius' art originates in a portrait of Puteanus sent by Horickius and is expressed for the first time by Puteanus on 1 May 1638 (cf. supra 15). The work seems to progress well in the beginning, Puteanus producing his eulogies one after the other, at first of the twelve German Emperors, then of Philip IV and the Cardinal-Infante. In the letters sent in 1638 to his friend, who clearly is a critical reader of the eulogist's first drafts, Puteanus refers to his work Purpura, a panegyric on the Habsburg besides an erudite treatise on the colour purple, published three years earlier, in $1635 .^{52}$ The year 1638 corresponds perfectly well with the dating in our manuscript of Horickius' signatures at the bottom of some of his eulogies of the Austrian emperors. So, Puteanus must have finished the eulogies of Maximilian, Rudolf I and II, Mathias, Ferdinand

51 The Latin title is used by Andrea de Solre in the dedication letter to Blitterswyck of his Musae Brabantinae centum anagrammata, ex uno Sanctissimi Domini nostri Alexandri VII [...] (Mechlinae, typis Gysberti Lintsii, 1666).

52 Epistolarum apparatus posthumus, Centuria VII, ep. 36, 46-47: "Elogia Austriacorum expendi serio magisque in hanc sententiam pertractus sum, ut existimem a Purpura abeundum non esse. Brevius certe nihil potest et fortassis nec aptius. De Romanis adhuc spatium posco, die Lunae daturus epistolam qua admirandus hic artifex commendetur. [...] Lovanii, in Arce, postrid. Non. Maii, M.DC.XXXVIII"; ibidem, ep. 3, 4-5: "Elogium Maximiliani Lipsii magis sensu quam verbis expressi, paucis omnino exceptis, quae e Seneca ille transtulit. Si vix igitur Lipsii est et non est, non meum, et meum. Sed me alia etiam caussa impulerat ut quod in Purpura non erat, aliunde viderer accepisse. Quod Rudolphum attinet, vilem ille solitus vestem gestare et sic conspicuus esse, tanquam externa ista ornamenta, ad viros non viros, aut non magnos relegaret. Id significare in Purpura obiter volui et paucorum verborum formula. Sed tecum sentio in elogio omitti posse. Rudolphum II, Mathiam, Ferdinandum II et III propediem missurus sum [...]. Lovanii, in Arce, VI. Eid. Junii M.DC.XXXVIII"; ibidem, ep. 45, 60-61: "Recte igitur monebas in Purpura reliqua elogia legi. Sed Horickio placere porro cupio. Philippum IV fratremque Ferdinandum? Pari, ut opinor, cum reliquis magnitudine habebit [...]. Lovanii, in Arce, prid. Eid. Sextil. M.D.C.XXXVIII." On Purpura, see E. Klecker, "Purpura non vellere, sed virtute nobilis. Panegyrische Tradition und literarische Originalität in Erycius Puteanus' Purpura Austriaca", Humanistica Lovaniensia 49 (2000), 301-315. 
II and III in the summer of the same year. ${ }^{53}$ Towards the end of the year, though, around October, things seem to slow down, despite Puteanus' promises on 2 October to procure Horickius in time with the necessary material. ${ }^{54}$ Over a year passes before the project is mentioned again in their correspondence. Puteanus apologizes towards Blitterswyck, who must have reminded him of Horickius, and seems less satisfied with Horickius' work. ${ }^{55}$

Hereafter things become more confusing, as Puteanus is clearly working contemporaneously on two different, yet intimately related, publications and it is not always easy to identify them in the correspondence: the portrait gallery in manuscript form for which Horickius has already made (part of) the lineographic illustrations and frames in 1638, and a printed and very much reworked version of some of these eulogies to which he potentially will add others. In September 1640 he sends Blitterswyck his text of John the Intrepid, in Latin Ioannes Intrepidus, which he has just finished, and asks him to have an error corrected in his

53 Epistolarum apparatus posthumus, Centuria VII, ep. 40, 51-52: "Nunc de isto Mathiae imperatoris elogio decerne, et elegantissimum Horickium salvere jube. Audeone beneficium a te petere? Debebo humanitati tuae si D. Lazaro Bonvicinio genero imperatores istos Horickii ostenderis. Adhuc, vale. Lovanii, in Arce, IV. Eid. Jul. M.DC.XXXVIII"; ibidem, ep. 41, 53-54: "Nunc Ferdinandi II elogium habe, satis, ut opinor, ad rem scriptum, quia novum penitus tanquam bonum mitto. Sic nunc igitur Horicium salvere jubeo, cui et primos Romanorum XII, libens daturus sum [...]. Lovanii, in Arce, XII Kal. Sextil. M.DC.XXXVIII"; ibidem, ep. 50, 66-67: "Cardinalis nostri Elogium mox dabo, ut aestimare Horickii artem magis magisque videar. Plasten tuum non minori affectu prosequor, qui si vivos vultus tam felici manu molietur, praecipuam picturae laudem ad se trahet [...]. Lovanii, in Arce, VII Kal. Octob. M.DC.XXXVIII."

54 Ibidem, ep. 51, 67-68: "Horickio nostro tempestive satisfaciam. Hactenus certe curae domesticae non permisere [...]. Lovanii, in Arce, postrid. Kal. Octob. M.DC.XXXVIII."

55 Ibidem, ep. 71, 90-91 (91): "De Horickio oblitus eram, sed quid mirum a pertinaci catarrhi nube madidam memoriam esse? Existimo igitur meliore imagine atque etiam titulo opus, quod parat, ornandum esse. Malim vero coram consilium meum aperire. Sic in adventum tuum omnia, ut vides, differo [...]. Lovanii, in Arce, IV Eid. Novemb. M.D.C.XXXIX." 
eulogy of Philip the Bold. ${ }^{56}$ The scribe of this eulogy in our manuscript, as of all the other eulogies of the Dukes of Burgundy, is not Horickius his participation here is clearly limited to the pages' decorative part - but Andreas Potheuck. The latter is further unknown to us, but in view of the many transcription errors which were moreover very clumsily corrected in the text, he does not seem to have been a professional scribe. More than once the scribe has not satisfactorily adapted his handwriting to the space which Horickius's elaborate frame offered him so that at the end the handwriting becomes smaller and the lines become more dense. If one were to publish these eulogies, it could not be in the form of these pages, and a new transcription would be necessary. So it is clear that in the 1640s Puteanus is working on the eulogies of the Dukes of Burgundy. In 1641 he writes to the poet Johannes Franciscus van Slingelandt (Slingelantius), secretary to Cardinal Bagni, and of the Great Council in Mechelen, that his work on the Elogia progresses slowly and sends the eulogy of Emperor Rudolf (1218-1291), ancestor of the Habsburg dynasty, prepared for the press "in specimen operis". ${ }^{57}$ In the summer of 1642 Puteanus writes to Gerard Vossius about his Theatrum heroicum: for the time being the work is limited to the eulogies of the Dukes of Burgundy and the Habsburg Emperors as well as Kings of Spain, but he will extend it in imitation of Paolo Giovio's Museum to other rulers and perhaps even to friends and colleagues. He adds that he wants his eulogies to be illustrated to enhance their prestige; to give him an idea of what it will look like he sends him the eulogies of Emperors Albert I (12551308) and Frederick the Fair (ca. 1289-1330); he has finished the eulogies

56 Ibidem, ep. 9, 11-12: "Quia igitur non venis, elogium Intrepidi, quod dare speraveram, mitto, accuratum, nisi omnino fallor. Sed in illo Audacis error est, sed numeri. Carolus enim inibi VI nominatur, V est; emendari cura. Opus sane sit tabella genealogica, ut recte historia intelligatur, quam cum Boni elogio simul habebis [...]. Lovanii, in Arce, III Eid. Septemb. M.DC.XL.” It is unclear to which passage of the eulogy of Philip the Bold Puteanus is referring: where he mentions Charles V and VI he is doing so correctly. But in our manuscript the passage about the death of Charles VI has been obscured, although still quite readable, while the printed version (see infra) has been profoundly altered.

57 Ibidem, Centuria IV, ep. 65, 100-101 (101): "In Theatro meo heroico sive Elogiis historicis pergo, sed lente. Rudolfus imperator gentis Austriacae auctor in specimen operis typis adornatus est, quem hic accipies. Lovanii, in Arce, postrid. Non. Octob. M.DC.XLI." On Van Slingelandt, see A.J. van der Aa in Biographisch woordenboek der Nederlanden: bevattende levensbeschrijvingen van zoodanige personen, die zich op eenigerlei wijze in ons Vaderland hebben vermaard gemaakt [...], Vol. 17 (Haarlem, 1863), 724. 
of the Dukes of Burgundy and grouped them together in his Orchestra Burgundica, which is in the press. ${ }^{58}$ In a letter to Caspar Barlaeus (15841648) Puteanus further elaborates on the idea of illustrating his work: the illustrations have to give colour to the text of his eulogies which are reduced to a simple set of lines. ${ }^{59}$

And yet, the Orchestra, that indeed came out in 1642, has but one portrait, of Charles $\mathrm{V}$, and that is because the text is followed by the emperor's genealogy in Spanish to which it undoubtedly belongs. ${ }^{60}$ The printed portrait, of bust-length and carrying the date 1531 , is not signed, but has been attributed to the German Barthel Beham (1502-1540). It has nothing to do with our Elogia. Although the text of the Orchestra differs in many points from the manuscript version in the Prodigium, both texts are clearly related to one another.

A year later, in 1643, follows the publication of his eulogies of the Spanish kings from the house of Habsburg up to Philip IV. ${ }^{61}$ And again, when we compare the printed version to the manuscript version it is very clear that, nothwithstanding their important differences, both are intimately related to one another, and show numerous verbal correspondences. With both the Orchestra Burgundica and the Podium Philippicum

58 Ibidem, Centuria III, ep. 69, 117-120 (119): "Theatrum nunc adorno Heroicum, sive Elogia imperatorum Austriacorum, ducum Burgundiae, regum Hispaniae, sed ex illis utrisque stirpe trahentium, ad alios deinde principes, exemplo Iovii (cuius olim museum perlustravi), operam translaturus. Iucundum sit viris etiam locum doctis et amicis dare. Statui vero et imagines a meliore manu addere et his auxiliis opus commendare quae si ulli libro, Elogiis certe conveniunt. Ut scriptionis formam videas, geminum hoc specimen mitto: Albertum, inquam, et Fredericum. Burgundiae duces una Orchestra absolvi, mox etiam transmittendos. Exemplaria enim a Typographo quotidie exspecto [...]. Lovanii, in Arci Regia, III Kal. Septembris MDCXLII."

59 Ibidem, Centuria III, ep. 70, 120-122 (122): "Eram in Elogiis Austriacis Burgundicisque, et ad te audeo affectus nomine specimen mittere. Inter historiam et laudationem medius sum, nisi utramque potius miscere videar. Rem narro, sed breviter, et haec quaedam velut lineae sunt; orno, sed leviter, et hi velut colores. Non debeo, ut scriptionis meae ratio est, uberius; non possum splendidius. Elogia sunt [...]. Lovanii, in Arce, prid. Kal. Septemb. M.D.C.XLII."

60 This at least is the situation in the copy I consulted in the Royal Library of Belgium, RP II 26316 B: Eryci Puteani Orchestra Burgundica. Ducum Burgundiae elogia historica. Pars theatri historici (Bruxellae, typis Ioannis Mommarti, 1642).

61 See n. 29. In the Prodigium they are followed by the eulogies of Archduke Albert of Austria, Balthasar Carlos prince of Asturias, and Cardinal-Infante Ferdinand of Austria. As already mentioned, the eulogies of the latter two end with the events of the year 1638. 
printed, only the eulogies on the emperors, with which the whole project had started, remained to be published. ${ }^{62}$

They will never be finalized in print, though, except for the already mentioned portrait of Charles V. If in April 1644 Puteanus is still actively working on this part of the project, a month later the whole project seems to Puteanus very much jeopardized by Horickius' state of health. ${ }^{63}$

\section{Conclusion}

In conclusion, the Prodigium is a composite manuscript, made at the request of a member of the Blitterswyck family, in memory of Horickius and his art, assembling single sheets partly from a never finished project, partly from what looks like left-overs. More importantly, it gives us insight into the creation of what had to become one of Puteanus' major works, a portrait gallery after Paolo Giovio's Museum. Puteanus' eulogies project evolved over time, from a manuscript tribute to the Habsburgs illustrated by probably the most respected calligrapher at the court of the Archdukes and of their successor in the Southern Netherlands, to a series of printed books, published independently, which carried the title Theatrum heroicum. Unfortunately, just like its example, Paolo Giovio's

${ }^{62} \mathrm{Cf}$. his letter to Constantin Huygens (1596-1687): "Vir summe equitumque decus, Podium nuper Philippicum misi [...]. Ad studia mea quod attinet, in Caesaribus pergo, et Rudolfi posteritate [...]. Lovanii, in Arce, IV. Kal. Majas, M.DC.XLIII": Ad Constantinum Hugenium et Danielem Heinsium, viros nobilissimos, epistolae, edente Marco Zverio Boxhornio Lugduni Batavorum, ex officina Francisci Hackii, 1647, ep. 26, 54-57. Cf. also his letter to the same of February of that year, ibidem, ep. 25, 52-54 (52-53): “[...] pluris est unum illud de Elogiis Caesarum Austriacorum epigramma tuum quam Elogia mea omnia [...] Mitto nunc (nec scio an miserim) Orchestram Burgundicam, partem quoque Theatri quod adorno, missurus mox et Podium Philippicum, sive reges quatuor Hispaniae Philippos, totidem Elogiis descriptos. Ubi Austriacos absolvero, ad alios quoque principes, bellique duces calamum transferam; quidni vero ad viros litteris et doctrina claros? [...] Lovanii, in Arce, V Kal. Mart. M.DC.XLIII."

63 Epistolarum apparatus posthumus, Centuria VI1, ep. 26 (to Blitterswyck), 33-34: "Caeterum ille noster artifex perquam iam difficilis est et aegre deinceps penicillum capit, sive quid pingendum, sive delineandum sit. Aetas et valetudo in caussa sunt, et vigorem hebetant, laborem recusant. In meis rebus vix illum ausim inter | pellare [...]. Lovanii in Arce, V Eid. Majas, M.DC.XLIV.” If the date is correct, then Puteanus has not yet been informed of the artist's death on 25 July 1643. 
Museum, the Theatrum would remain a work in progress. It was abandoned most probably due to the passing away of its principal actors.

Koninklijke Bibliotheek van België wouter.bracke@kbr.be 


\section{Figures}

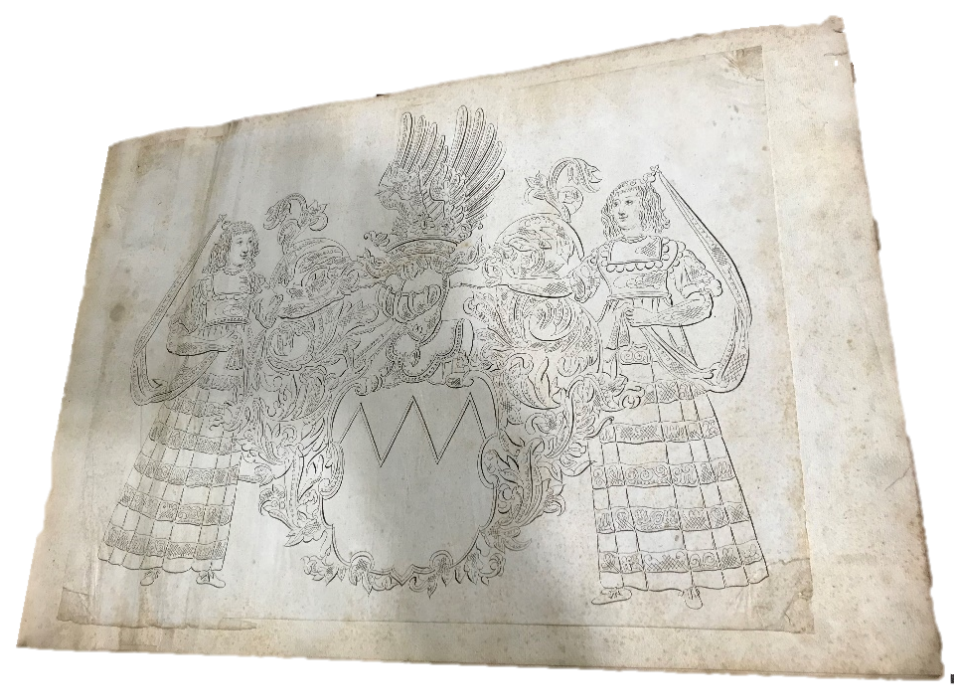

Plate 1: The arms of the Blitterswyck family (The Newberry Library, Wing MS ZW 6465 .H782, f. 2r) 


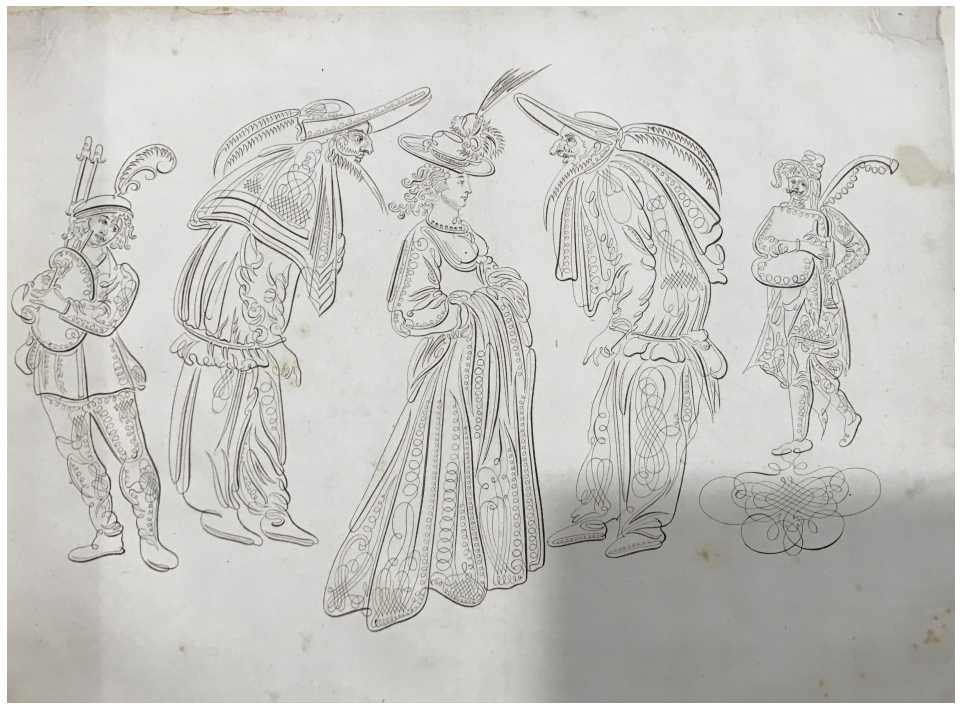

Plate 2: Drawings after Jacques Callot (The Newberry Library, Wing MS ZW 6465 .H782, f. 65r)

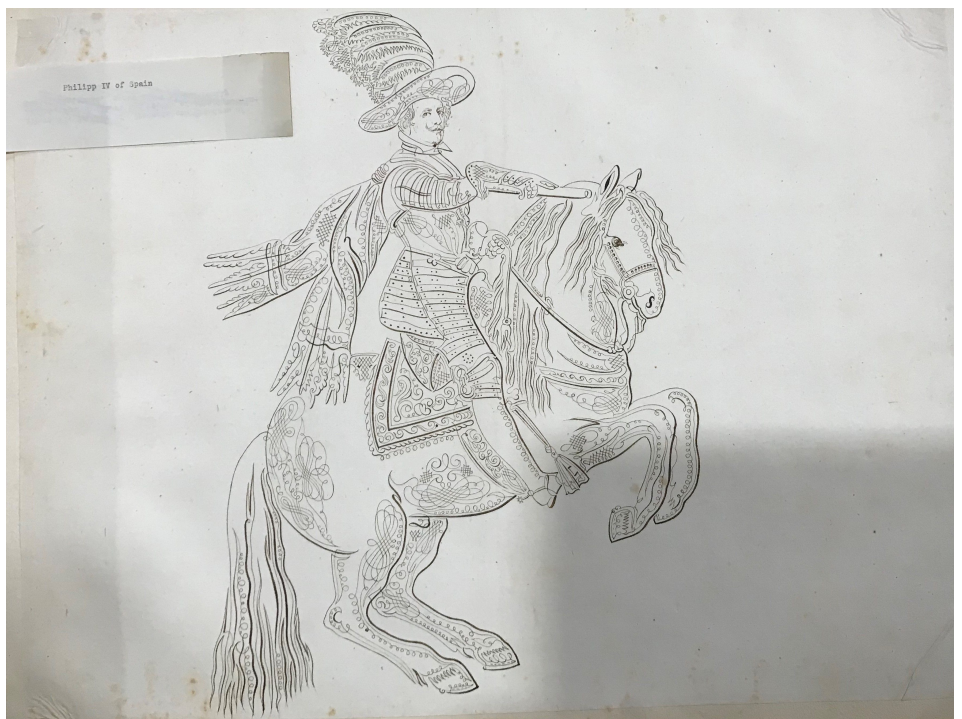

Plate 3: Equestrian portrait of Philip IV (The Newberry Library, Wing MS ZW 6465 .H782, f. 54r) 